\title{
Factors Affecting Customers' Brand Choice Behavior of Semi Processed Frozen Food Products: A Study in Khulna City, Bangladesh
}

\author{
S. M. Monirul Islam ${ }^{1, *}$, Abul Kalam ${ }^{2}$, Afia Fahmida ${ }^{3}$ \\ ${ }^{1}$ Department of Business Administration, Northern University of Business and Technology Khulna, Bangladesh \\ ${ }^{2}$ Marketing, Department of Business Administration, HDSTU, Bangladesh \\ ${ }^{3}$ Department of Business Administration, Bangladesh Army University of Engineering \& Technology, Bangladesh
}

Copyright $\bigcirc 2018$ by authors, all rights reserved. Authors agree that this article remains permanently open access under the terms of the Creative Commons Attribution License 4.0 International License

\begin{abstract}
This paper investigates the determinants of consumers' choice of semi processed frozen snacks food products (especially snacks category) and develops an empirical understanding of the factors affecting customers' choice behavior. We have chosen this study to look specifically at processed frozen snacks and breakfast products as they represent a rapidly increasing segment of the restaurant snacks and breakfast replacement category. In this research descriptive statistics and factor analysis have been conducted to identify the factors that actually affect Consumers' decision in selecting semi processed frozen food products of different brands. Responsiveness has been got regarding the factors like brand image, quality, how much hygiene, price, processing time etc. Eight salient features of the product were selected after a pretesting consumer survey and initial discussion with the channel members. After analyze the total variance it is found that three principal components are liable for more than $60 \%$ of total variance, each of which initial Eigen value is also more than 01 (required). After varimax rotated component matrix analysis it is found that 5 variables i.e. product quality, price, taste, availability and competitive superiority, are strongly correlated with the three principal components.
\end{abstract}

Keywords Consumer Choice, Frozen Foods, Factor Analysis

\section{Introduction}

Once a time, people made everything as possible by themselves for fulfilling their own needs. Later the civilization has been growing up and work specialization got preference, which refers that an individual or a group of people will produce a certain goods or service as their expertise and remaining everything they will purchase from other people who have expertise on those. This concept made the industries more productive, economic and professional. Food is the basic human need (Maslow, A. [1] 1943), because of the physiological category of needs the potentiality of food industry will remain until the human being exists in the planet. Due to the lack of time to prepare own food and consumers' focus on professional production; processed/semi processed and ready food industry becomes multibillion dollar industry in developed countries, even in the developing and under developed countries like Bangladesh the demand of this industry is growing fast. In urban life the time constraint is increasing day by day, people are busy with their professional works and business, time for household is reducing. Even the females don't have much time for managing the household as they are now actively participating in higher education, professional service, business and other jobs, especially in urban areas. In this demographic and social atmosphere urban people are interested in to the time saving value of different products. In respect of this awareness, semi processed frozen food products have already become very essential needs of the urban people in Bangladesh. At present, more than 50 different types of products covering a wide range of categories like semi processed fish finger, shrimps finger, beef/chicken burger, processed chicken, semi processed vegetable/chicken rolls, Samosa, Singara, French fries, porata, rooti, sandwich and other breakfast and snacks item.

Khulna is one of the district and divisional cities of Bangladesh; in respect of area, it ranks $1^{\text {st }}$ among the 10 districts in Khulna division and $4^{\text {th }}$ among the 64 districts of the country. According to the population census 2011, total number of households of Khulna district was 547000 which was $1.70 \%$ of total households of the country. The total number of population of the district was 2313000 which was $1.60 \%$ of total population of the country. (BBS: 
District statistics, 2013 [2]). Considering the location, economy and demography Khulna city is an important market for the different companies operated in Bangladesh. At present semi processed frozen products are being producing and marketing by different manufacturing companies of Bangladesh like BRAC food ltd. Pran Food Ltd, Squire Food ltd. Golden Harvest food ltd., Lamisa Food Ltd., etc. Considering the potentiality of the industry this study has strived to explore the factors that affecting consumers' brand choice decision to purchase the semi processed frozen food products.

\section{Literature Review}

Several studies have been conducted to explain consumer brand choice behavior in different industries. Most studies examined consumer brand and product choice behavior in association with demographic and socio economic characteristics. However attitude and behavioral characteristic are also highlighted as important determinants of product and brand choice than demographic and socio-economic characteristic (Baltas, George. [3], 1997). Consumer previous knowledge and experience have greater extent to prefer the brand, but it depends on the weight of consumer prior knowledge and cognitive ability (Bettman, J.R and Park, C.W. [4], 1980). And other researchers proved that perceptions of quality and other features of the products have strong capacity to influence individuals buying behavior prior to demographic, psychological and shopping behavior (Szymanski, DM. and Busch PS [5], 1987). Whereas familiarity with store brand, extrinsic cues (such as price and package), perceived quality variation, perceived risk, and perceived value for money, income and family size are example of factors influencing consumers' product choice behavior (Dick, Alan, Arun Jain, and Paul Richardson. [6], 1996). Additional study also showed the difference perception of consumers in the marketing stimuli results different in action of purchasing behavior (Livesey, F; Lennon, P. [7], 1978).

Janjaap Semeijn [8] and co-researchers investigated how store image factors and various categories of perceived risk associated with product attributes affect consumer evaluations of store-branded products. They used a structural model and tested, providing indications of the likelihood of store brand success in various product categories. It was found that Store image and quality, Product attributes and related risks, Product complexity and functional risk affects the consumer evaluation of store brands. (J. Semeijn et al.2004).

Masoom, M.R. [9] and coauthors studied Factors Affecting the Consumer Purchasing Decisions of Perishable Foods in Bangladesh to explore the consumers Attitudes and the Preferences. The study focuses on the quality of Vegetable, fish and meat (VFM) available in the market and tried to identify the importance of the parameters for VFM attached with quality, quality parameters for VFM evaluated by consumers, actual quality of VFM perceived by consumers, and the quality gaps prevailing in the market. And they found that color, taste, smell, size, source, freshness, fat, dirt, preservation method etc. affects Consumer Purchasing Decisions of Perishable Foods in Bangladesh. (Masoom, M.R. et al., 2015).

Goldman, A., Ramaswami, S., and Krider, R.E. [10] presented a framework in 2002 on the Barriers to the advancement of modern food retail formats. In a 1995 diagnostic study, they found that geographic and economic segment diffusion of supermarkets is complete, but that product category-dependent diffusion (specifically perishables) is not. The latter, thereby, becomes the major restriction on supermarket share gain. In 1999, their second study measures the impact of the introduction of superstores, a large modern format, on the perishable restriction to modern format share growth. Consumers perceived superstore perishables to be superior to supermarkets', but these views had little impact on the ability of modern format to wrest additional share from traditional markets. (Goldman, A., Ramaswami, S., and Krider, R.E., 2002)

\section{Objectives of the Study}

The prime objective of the study is to explore customers' purchasing behavior of semi processed frozen food products in Khulna city, Bangladesh.

More specifically;

- $\quad$ To identify the potential factors considered by the customers of semi processed frozen food products to take purchase decisions

- To extract the principle factors that influence the brand and/or product choice decisions of semi processed frozen food products customers

- To prepare some empirical guidelines for the companies of semi processed frozen food industry of Bangladesh to make their offering more customers driven to capitalize the market opportunities.

\section{Methodology}

The methodology followed to conduct the study was as follows;

\subsection{Factor Selection}

To identify the potential factors of semi processed frozen food products those have major influence on brand and/or product choice decision of Bangladeshi customers, we conducted a pretest on 18 preliminary selected attributes 
with 48 sample customers. We determine the cutoff line of $50 \%$ that means if at least $50 \%$ pretest sample respondents think the factor is important enough to consider for taking purchase decision of semi processed frozen food products then that particular factor would be consider for final survey. In the pretest 08 factors were above the cutoff line, so those 08 factors were selected for analyzing factor influence of customers' purchase decisions.

\subsection{Sample and Data Collection}

To conduct final survey on the selected 08 factors of semi processed frozen food products for determining influencing factors of customers' product choice behavior 100 customers of semi processed frozen food products were selected conveniently from Khulna city.

The data were collected from the sample respondents through a structured questionnaire. To measure the perception of the respondents on selected 11 attributes of ecommerce site 5 point Likert scale were used (CR. Kothari [11], 2004).

\subsection{Data Analysis}

Collected data have been analyzed through appropriate statistical tools; Demographic data of the respondents were analyzed by descriptive statistic. Responses of the sample customers towards the factors were analyzed by using principle component analysis (factor analysis) model. To justify the sample size Kaiser-Meyer-Olkin (KMO) adequacy test were conducted. To measure sphericity of correlation among factors Bartlett's test were conducted. (Malhotra N. K. [12], 2010).

To process the data and extract the essential statistics for aforesaid methodology SPSS 16.0 was used.

\section{Result and Discussion}

In the questionnaires, we selected eight important factors which have significant influence on customer's choice of purchasing frozen processed food. Factor analysis is conducted on those nine factors. These nine factors through review of relevant literature and also through a pilot survey on a small sample.

\subsection{Demographic Profile Analysis}

In the questionnaires, respondents are asked about their occupation, age, gender and income. The results of their response are as follows:

\subsubsection{Occupation}

In the survey, 100 people gave their opinion about their consideration of factors in purchasing frozen processed food. The total population is divided into four divisions depending on their occupation which are student, housewife, service and business. In the table below, 26\% are students, $30 \%$ are housewives, $24 \%$ are service holder and rest of the $20 \%$ is businessmen. These percentages of the respondents are shown in the table below.

Table 5.1.1. Occupational composition of the respondent

\begin{tabular}{|c|c|c|c|c|c|}
\hline & Frequency & Percent & $\begin{array}{c}\text { Valid } \\
\text { Percent }\end{array}$ & $\begin{array}{c}\text { Cumulative } \\
\text { Percent }\end{array}$ \\
\hline \multirow{5}{*}{ Valid } & Student & 26 & 26.0 & 26.0 & 26.0 \\
\cline { 2 - 6 } & Housewife & 30 & 30.0 & 30.0 & 56.0 \\
\cline { 2 - 6 } & service & 24 & 24.0 & 24.0 & 80.0 \\
\cline { 2 - 6 } & Business & 20 & 20.0 & 20.0 & 100.0 \\
\cline { 2 - 6 } & Total & 100 & 100.0 & 100.0 & \\
\hline
\end{tabular}

\subsubsection{Gender}

In the survey, $64 \%$ of the total sample was female and another $36 \%$ are male. As in Bangladeshi household culture female are generally responsible food item and now a days they are working outside, so frozen processed food will make their work easier by saving time on it, so we have given some extent of priority to female respondents.

Table 5.1.2. Gender of the Respondent

\begin{tabular}{|c|c|c|c|c|c|}
\hline & Frequency & Percent & $\begin{array}{c}\text { Valid } \\
\text { Percent }\end{array}$ & $\begin{array}{c}\text { Cumulative } \\
\text { Percent }\end{array}$ \\
\hline \multirow{3}{*}{ Valid } & Male & 36 & 36.0 & 36.0 & 36.0 \\
\cline { 2 - 6 } & Female & 64 & 64.0 & 64.0 & 100.0 \\
\cline { 2 - 6 } & Total & 100 & 100.0 & 100.0 & \\
\hline
\end{tabular}

\subsubsection{Age}

On the basis of age, respondents are divided into three classes. About $44 \%$ people are in the range of $18-30,40 \%$ of people are between $31-40$ and other $16 \%$ people are between the ages of 41-50. Here, the respondents between the ages of 18-40 are given priority as they are out going and working people. So, frozen processed food can help them by making their work easier. The age range of the respondents and their percentages are presented through table and graphical presentation.

Table 5.1.3. Age of the respondents

\begin{tabular}{|c|c|c|c|c|c|}
\hline & Frequency & Percent & $\begin{array}{c}\text { Valid } \\
\text { Percent }\end{array}$ & $\begin{array}{c}\text { Cumulative } \\
\text { Percent }\end{array}$ \\
\hline \multirow{4}{*}{ Valid } & $18-30$ & 44 & 44.0 & 44.0 & 44.0 \\
\cline { 2 - 6 } & $31-40$ & 40 & 40.0 & 40.0 & 84.0 \\
\cline { 2 - 6 } & $41-50$ & 16 & 16.0 & 16.0 & 100.0 \\
\cline { 2 - 6 } & Total & 100 & 100.0 & 100.0 & \\
\hline
\end{tabular}




\subsubsection{Income}

The questionnaires were set dividing the economic status of the respondents into six groups based on their monthly income. People between the income range of 1000-10000 are 56\% of the total respondents. That means, students and housewives are taking frozen processed food in large scale and the context of Bangladesh most of the housewives and students have no income or a little, their consumptions are basically dependent of their parent's or spouse's income. The percentage of other income range (i.e. above 10000) is $44 \%$ in total.

Table 5.1.4. Income range distribution of the respondents

\begin{tabular}{|c|c|c|c|c|c|}
\hline & & Frequency & Percent & $\begin{array}{c}\text { Valid } \\
\text { Percent }\end{array}$ & $\begin{array}{c}\text { Cumulative } \\
\text { Percent }\end{array}$ \\
\hline \multirow{5}{*}{ Valid } & $1000-10000$ & 56 & 56.0 & 56.0 & 56.0 \\
\cline { 2 - 6 } & $10000-20000$ & 4 & 4.0 & 4.0 & 60.0 \\
\cline { 2 - 6 } & $20000-30000$ & 6 & 6.0 & 6.0 & 66.0 \\
\cline { 2 - 6 } & $30000-40000$ & 8 & 8.0 & 8.0 & 74.0 \\
\cline { 2 - 6 } & $40000-50000$ & 12 & 12.0 & 12.0 & 86.0 \\
\cline { 2 - 6 } & $50000+$ & 14 & 14.0 & 14.0 & 100.0 \\
\cline { 2 - 6 } & & & & & \\
\hline
\end{tabular}

\subsection{Factor Analysis}

To continue towards the main analysis, factor analysis has been performed to identify the key factors affecting consumer's choice of purchasing frozen processed food. The respondent's ratings are subject to principal axis factoring with varimax rotation to produce potential multico-linearity among the items and to improve reliability on the data. Eight factors are reduced to three orthogonal factor dimensions which explained $60 \%$ of overall variance indicating that the variance of original values is well captured by these three factors.

Table 5.2.0. Descriptive Statistics

\begin{tabular}{|c|c|c|c|}
\hline Factors & Mean & Std. Deviation & Analysis N \\
\hline Brand image of the product & 3.7600 & .88899 & 100 \\
\hline Quality of the product & 4.9500 & .26112 & 100 \\
\hline Price of the product & 3.9000 & .83485 & 100 \\
\hline Availability of the product & 3.7400 & .91696 & 100 \\
\hline Seek alternatives before buying & 3.3200 & .67987 & 100 \\
\hline Taste of the product & 3.8200 & .82118 & 100 \\
\hline Packaging of the product & 3.1000 & .88192 & 100 \\
\hline Promotional incentives & 3.3200 & 1.81397 & \\
\hline
\end{tabular}

Table 5.2.1. KMO and Bartlett's Test

\begin{tabular}{|l|c|c|}
\hline \multicolumn{2}{|c|}{ Kaiser-Meyer-Olkin Measure of Sampling Adequacy. } & .533 \\
\hline \multirow{3}{*}{ Bartlett's Test of Sphericity } & Approx. Chi-Square & 105.245 \\
\cline { 2 - 3 } & df & 28 \\
\cline { 2 - 3 } & Sig. & .000 \\
\hline
\end{tabular}

From the table 5.2.1, it is observed that KMO is 0.533 that is more than the required value of 0.50 . It indicates that there is no error in $53.3 \%$ of the sample and in the remaining $46.7 \%$, there may be some sort of error. Bartlett's test of sphericity indicates that strength of relationship among variables is strong. It presents good idea to proceed to factor analysis for the data. 
HO : There is a significant indifference of all the factors affecting consumer behavior

H1: There is a significant difference of all the factors affecting consumer behavior

The value of chi-square test (105.245 with significance level of .000) signifies the rejection of null hypothesis. It means that there is a significant difference among the factors that affect consumers' choice of frozen processed food. Communality of each statement refers to the variance being shared or common by other statements. From the communalities (Table 3.3), it can be seen that the communality for each variable; V1 to V8 is 1.0. In table 3.4, the Eigen values for the factors are, as expected, in decreasing order of magnitude as going from component or factor 1 to component or factor 8 . Eigen value for a factor indicates the total variance attributed to the factor. The total variance accounted by the 08 factors is 8 . The Eigen value of facto 1, factor 2 and factor 3 are sequentially 2.004, 1.466 and 1.331, which is more than the required level of 1 .

Table 5.2.3. Communality of variables

\begin{tabular}{|c|c|c|}
\hline \multicolumn{2}{|c|}{ Communalities } & Extraction \\
\hline Brand image of the product & 1.000 & .659 \\
\hline Quality of the product & 1.000 & .321 \\
\hline Price of the product & 1.000 & .576 \\
\hline Availability of the product & 1.000 & .737 \\
\hline Seek alternatives before buying & 1.000 & .673 \\
\hline Taste of the product & 1.000 & .534 \\
\hline Packaging of the product & 1.000 & .715 \\
\hline Promotional incentives & 1.000 & \multicolumn{2}{|c|}{} \\
\hline Extraction Method: Principal Component Analysis. & \\
\hline
\end{tabular}

Table 5.2.4. Total Variance Explained

\begin{tabular}{|c|c|c|c|c|c|c|c|c|c|}
\hline \multirow{2}{*}{ Component } & \multicolumn{4}{|c|}{ Initial Eigenvalues } & \multicolumn{3}{c|}{ Extraction Sums of Squared Loadings } & \multicolumn{3}{|c|}{ Rotation Sums of Squared Loadings } \\
\cline { 2 - 10 } & Total & \% of Variance & Cumulative \% & Total & \% of Variance & Cumulative \% & Total & $\begin{array}{c}\text { \% of } \\
\text { Variance }\end{array}$ & $\begin{array}{c}\text { Cumulative } \\
\%\end{array}$ \\
\hline 1 & 2.004 & 25.048 & 25.048 & 2.004 & 25.048 & 25.048 & 1.739 & 21.732 & 21.732 \\
\hline 2 & 1.466 & 18.329 & 43.377 & 1.466 & 18.329 & 43.377 & 1.603 & 20.037 & 41.769 \\
\hline 3 & 1.331 & 16.641 & 60.018 & 1.331 & 16.641 & 60.018 & 1.460 & 18.249 & 60.018 \\
\hline 4 & .905 & 11.306 & 71.324 & & & & & & \\
\hline 5 & .791 & 9.893 & 81.218 & & & & & & \\
\hline 6 & .632 & 7.901 & 89.118 & & & & & & \\
\hline 7 & .477 & 5.967 & 95.085 & & & & & & \\
\hline 8 & .393 & 4.915 & 100.000 & & & & & & \\
\hline
\end{tabular}

Extraction Method: Principal Component Analysis.

Factor 1 accounts for a variance of 2.004 which is the $25.048 \%$ (2.004/8) of the total variance. Factor 2 accounts for a variance of 1.466 which is the $18.329 \%$ (1.466/8) of the total variance. Factor 3 accounts for a variance of 1.331 which is the $16.641 \%(1.331 / 8)$ of the total variance. It can be interpreted that 08 variables are now reduced to 03 components or factors contributing $60.018 \%$ of the total variance, which defines that factors affecting consumer choice of buying frozen processed food.

With the help of scree plot researcher can just visualize that 3 factors are reduced with Eigen value greater than 1.000. Table 5.2.5 reports the factor loadings for each variable on the unroated components or factors. Each number represents the correlation between the items and the unroated factor. This correlation helps to formulate an interpretation of the factors or components. This is done by looking for a common tread among the variables that have large loadings for a particular factor or component. 
Factors Affecting Customers' Brand Choice Behavior of Semi Processed Frozen Food Products:

A Study in Khulna City, Bangladesh

Table 5.2.5. Component Matrix

\begin{tabular}{|c|c|c|c|}
\hline \multicolumn{4}{|c|}{ Component Matrix } \\
\hline & \multicolumn{3}{|c|}{ Component } \\
\hline Brand image of the product & 1 & 2 & -.252 \\
\hline Quality of the product & .124 & -.762 & -.316 \\
\hline Price of the product & -.132 & .452 & -.326 \\
\hline Availability of the product & .652 & .212 & .704 \\
\hline Seek alternatives before buying & .482 & .658 & .321 \\
\hline Taste of the product & -.216 & .332 & .149 \\
\hline Packaging of the product & .736 & -.218 & -.244 \\
\hline Promotional incentives & -.654 & -.191 & .618 \\
\hline
\end{tabular}

Extraction Method: Principal Component Analysis.

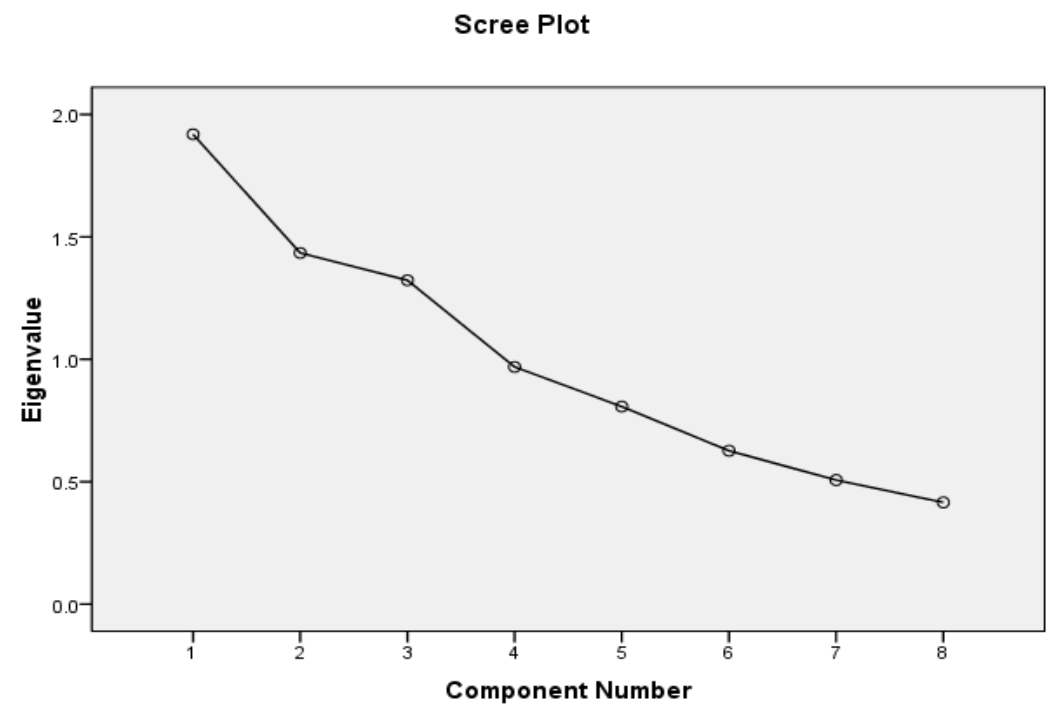

Figure 1. Component Number

Table 5.2.6. Rotated Component Matrix

\begin{tabular}{|c|c|c|c|c|}
\hline \multicolumn{2}{|c|}{} & \multicolumn{3}{|c|}{ Rotated Component Matrix } \\
\hline SL & & 1 & 2 & 3 \\
\hline 1 & Brand image of the product & -.026 & .039 & -.811 \\
\hline 2 & Quality of the product & .227 & -.410 & .319 \\
\hline 3 & Price of the product & .749 & .123 & -.020 \\
\hline 4 & Availability of the product & -.053 & .852 & .094 \\
\hline 5 & Competitive performance over substitute & -.118 & -.025 & .754 \\
\hline 6 & Taste of the product & .593 & .510 & .251 \\
\hline 7 & Packaging of the product & -.291 & -.638 & .207 \\
\hline 8 & Promotional incentives & -.820 & .159 & .130 \\
\hline
\end{tabular}

Extraction Method: Principal Component Analysis.

Rotation Method: Varimax with Kaiser Normalization.

a. Rotation converged in 5 iterations. 
It is possible to see them with large loadings on several of the unroated factors, which makes interpretation difficult. Before rotation (table 5.2.5), the correlation of each value for factor 1,2 and 3 is more than the required level (0.30) which is difficult to take decision on variables. In these cases, it can be helpful to examine a rotated solution. The rotated factor matrix (table 5.2.6) makes it simple to take decision. Factor 1 has deep relationship with variable 6 and 3; factor 2 has deep relationship with variable 4 ; factor 3 has deep relationship with variable 2 and 5 .

With the help of table 5.2.6 we can categorize each statement depending upon factor loadings and are shown below. If table 5.2.6is observed carefully, it can be found that a highest loading of each variable is categorized under each factor.

\section{Factor 1: (Product and price benefits)}

- $\quad$ Price of the product

- Taste of the product

Factor 2: (Effective distribution)

- Availability of the product

Factor 3: (Brand Superiority)

- Competitive performance over substitute

- Quality of the product

From the table 5.2.6, we can obtain the quantifiable data of each factor. The factors are labeled considering the strength of association with the variables. The coefficient between the statements and the factors are taken according to the statement affecting the factor. Factor 1 includes Price of the product and taste of the product that was named product and price benefits. Factor 2 includes availability of the product and it was named effective distribution. Factor 3 includes competitive performance over substitute and quality of the product, was named superiority.

\section{Conclusions}

After analyzing all the factors within the predetermined framework it is found that consumers' purchase decisions of semi processed frozen food products are significantly affected by five factors such as quality, taste, price, availability, and competitive superiority of the product over other substitute or competitive brands. Among these five factors influence of availability of the product is greater than the influence of any others, because this type of product is convenient product, consumers need it daily basis, so uninterrupted availability is an important concern to the consumers. The study also reveals that the competitive superiority also a great concern to the customers, that means they are not much loyal to any brand in this category. If they find any other brand offers more value they will switch to it. The lack of brand loyalty also reflected in the factor analysis, there it is presented that brand image of the product is insignificant to consumers. The beautification in packaging is also insignificant to the consumers for semi processed frozen food products. So the companies in the studied industry in Bangladesh should concentrate to effective and errorless distribution system, quality, taste and price of the product. Moreover they should also very responsive to completive offering as there is a lack of brand loyalty.

\section{REFERENCES}

[1] Maslow, A. H. "A Theory of Human Motivation." Psychological Review, Vol. 50, 370-396, 1943

[2] Statistics, Bangladesh Bureau of. http://www.bbs.gov.bd/site/page/2888a55d-d686-4736-bad 0-54b70462afda/District-Statistics. June 26, 2013.

[3] Baltas, George. "Determinants of store brand choice: a behavioral analysis." Journal of product and brand management 6, no. 5 (1997): 315-324.

[4] Bettman, James R., and C. Whan Park. "Effects of prior knowledge and experience and phase of the choice process on consumer decision process: A protocol analysis." Journal of consumer research 7, no. 3 (December 1980): 234-248.

[5] Szymanski, D. M., and P. S. Busch. "Identifying the generics-prone consumer: a meta-analysis." Journal of Marketing Research 24, no. 4 (1987): 425-431.

[6] Dick, Alan, Arun Jain, and Paul Richardson. "How consumers evaluate store brands." Journal of Product \& Brand Management 5, no. 2 (1996): 19-28.

[7] Livesey, F., and P. Lennon. "Factors Affecting Consumers' Choice between Manufacturer Brands and Retailer Own Labels." European Journal of Marketing 12, no. 2 (1978): 158-170.

[8] Semeijn, Janjaap, Allard C.R. van Riel, and A. Beatriz Ambrosini. "Consumer evaluations of store brands: effects of store imageand product attributes." Journal of Retailing and Consumer Services 11 (2004): 247-258.

[9] Masoom, Muhammad Rehan, Syed Habib Anwar PASHA, and S.M. Asif-Ur RAHMAN. "Factors Affecting the Consumer Purchasing Decisions of Perishable Foods: Exploring the Attitudes and the Preferences." Management Dynamics in the Knowledge Economy 3, no. 3 (2015): 509-531.

[10] Goldman, Arieh, S. Ramaswami, and Robert E. Krider. "Barriers to the advancement of modern food retail formats: theory and measurement." Journal of Retailing 78, no. 4 (2002): 281-295.

[11] Kothari, C.R. Research Methodology: Methods and Techniques. 3rd. New Delhi: New Age International Publishers, 2004.

[12] Malhotra, Naresh K., and Dash Satyabhusan. Marketing Research: An Applied Orientation. 6th. New Delhi: Prentice Hall, 2010. 